\title{
DELIMITACJA WOJEWÓDZTW ZE WZGLĘDU NA INFRASTRUKTURĘ TRANSPORTOWĄ I JAKOŚĆ NAWIERZCHNI
}

\begin{abstract}
Rozwój społeczno-gospodarczy państw wiąże się rozwojem infrastruktury transportowej, która umożliwia szybkie przemieszczanie się ludzi i towarów. Obecna eksploatacja sieci drogowej, gdy ruch drogowy się nasila, jest coraz większa. Dlatego niezwykle ważnym procesem staje się szybkie diagnozowanie stanu nawierzchni oraz kierowanie środków w najbardziej potrzebne regiony tak, aby zapobiegać jeszcze większej dewastacji i aby dbać o bezpieczeństwo w ruchu drogowym. Celem artykułu jest nie tylko diagnoza stanu nawierzchni w województwach w Polsce, ale także powiązanie go z infrastrukturą drogową, transportową i bezpieczeństwem na drogach. Ze względu na złożoność problemu do badań wykorzystano mierniki, za pomocą, których podjęto próbę określenia problemu. Przy doborze cech zastosowano dotychczasową wiedzę i doświadczenie badawcze. Głównym kryterium doboru wskaźników był dostęp do baz danych oraz analiza statystyczna. Do badań wykorzystano metody wielowymiarowej analizy porównawczej (WAP). Dane obejmują 2014 r. i pochodzą z bazy Głównego Urzędu Statystycznego oraz zasobów GDDKiA. Badania prowadzono, wykorzystując do obliczeń program Statistica 10.1 PL oraz EXCEL 2007. W wyniku badań otrzymano trzy grupy województw podobnych do siebie pod względem badanych cech. Poziomy analizowanych wskaźników w tych skupieniach są zróżnicowane. Jednakże stwierdzić można, że od 2000 roku stan polskich dróg nieustannie się poprawia.

Slowa kluczowe: transport, taksonomia, infrastruktura transportowa
\end{abstract}

\section{WPROWADZENIE}

Jednym z najważniejszych działów gospodarki o strategicznym znaczeniu dla kraju jest transport, który obejmuje trzy główne sfery: gospodarczą, polityczną i turystyczną w wymiarze zarówno regionalnym, jak i krajowym oraz międzynarodowym ${ }^{2}$. Dlatego niezwykle ważną rolę odgrywa infrastruktura transportowa, bez której przemieszczanie się ludzi i towarów nie miałoby racji bytu. Dobrze rozwinięta oraz nowoczesna sieć autostrad, dróg ekspresowych i dróg szybkiego ruchu ${ }^{3}$ jest warunkiem właściwego funkcjonowania krajów rozwiniętych gospodarczo ${ }^{4}$. Infrastruktura transportowa stanowi więc podstawę funkcjonowania gospodarki

${ }^{1}$ Dr Katarzyna Chudy-Laskowska, Katedra Metod Ilościowych, Politechnika Rzeszowska, e-mail: kacha877@prz.edu.pl

${ }^{2} \mathrm{~J}$. Sidor,Realization of the transport policy at the international, national and regional level,„Eksploatacja i Niezawodność - Maintenance and Reliability” 2006/4, s. 61-66.

${ }^{3}$ Zgodnie z definicją zawartą w Słowniku Pojęć Strategii Rozwoju Transportu do 2020 r. (z perspektywą do 2030 r.) droga szybkiego ruchu to potoczne określenie drogi głównej ruchu przyspieszonego, która jest oznaczona symbolem GP, zgodnie z Rozporządzeniem Ministra Transportu i Gospodarki Morskiej z 2 marca 1999 r. w sprawie warunków technicznych, jakim powinny odpowiadać drogi publiczne i ich usytuowanie (Dz.U. nr 43, poz. 430 ze zm.).

${ }^{4}$ J.E. Sturm, J. Jacobs,P. Groote,Output effects of infrastructure investment in the Netherlands, 1853-1913,„Journal of Macroeconomics” 1999/21;M. Farhadi,Transport infrastructure and long- 
i powiązana jest ze wszystkimi jej działami. Tworzą ją w głównej mierze trzy podstawowe czynniki:

- drogi wszystkich rodzajów transportu (drogowego, kolejowego, śródlądowego, morskiego i powietrznego);

- punkty transportowe (węzły drogowe, lotniska, porty, itp.);

- urządzenia pomocnicze służące do bezpośredniej obsługi dróg i punktów transportowych ${ }^{5}$.

Infrastruktura jest pojęciem międzynarodowym, oznaczającym zespół podstawowych obiektów, urządzeń i instytucji o charakterze usługowym niezbędnym do właściwego funkcjonowania społeczeństwa i produkcyjnych działów gospodarki ${ }^{6}$. Infrastrukturę transportową stanowią infrastruktury poszczególnych rodzajów transportu: samochodowego, kolejowego, morskiego, lotniczego oraz żeglugi śródlądowej. Zdecydowanie dominującą rolę zarówno pod względem wykonanej pracy przewozowej $(69,2 \%)$, jak i przewiezionej masy ladunków $(75,6 \%)$ odgrywa transport drogowy ${ }^{7}$.

Krajowa infrastruktura drogowa wymaga dużych nakładów na rozwój i zapewnienia odpowiednich standardów istniejącej sieci, aby możliwe było sprostanie potrzebom rynku, wynikającym ze wzrostu wymiany towarowej oraz stale rosnącego ruchu pasażerskiego. Im lepiej rozwinięta infrastruktura drogowa i transportowa, tym większe możliwości wzrostu gospodarczego ${ }^{8}$ oraz większe bezpieczeństwo $\mathrm{w}$ ruchu drogowym ${ }^{9}$.Większość wartości minimalnych i maksymalnych parametrów projektowych oraz uwarunkowań projektowych zebranych jest w formie Rozporządzenia Ministra Transportu i Gospodarki Morskiej w sprawie warunków technicznych, jakim powinny odpowiadać drogi publiczne i ich usytuowanie (Dz.U. z 14 maja 1999, nr 43, poz. 430).

Rozporządzenie określa warunki techniczne, jakim powinny odpowiadać drogi publiczne przy zachowaniu przepisów prawa budowlanego, przepisów o drogach publicznych oraz przepisów odrębnych, a także ustaleń polskich norm, w szczególności podstawowych wymagan ${ }^{10}$ :bezpieczeństwa użytkowania, nośności i stateczności konstrukcji, bezpieczeństwa ze względu na możliwość wystąpienia pożaru lub innego miejscowego zagrożenia oraz ochrony środowiska, ze szczególnym uwzględnieniem ochrony przed nadmiernym hałasem, wibracjami, zanieczyszczeniami powietrza, wody i gleb ${ }^{11}$.Sieć dróg krajowych, chociaż

run economic growth in OECD countries,„,Transportation Research Part A. Elsevier” 2015/74, s. 73-90.

${ }^{5}$ G. Nowacki,Wybrane problemy dotyczace infrastruktury transportowej oraz potencjalnych zagrożeń terrorystycznych, Instytut Transportu Samochodowego, Warszawa 2012.

6W. Mirowski,Studia nad infrastruktura wsi polskiej. Wyposażenie obszarów w infrastrukturę społeczna,t. III, PAN Instytut Rozwoju Wsi i Rolnictwa, Warszawa 1996.

${ }^{7}$ M. Jacyna, D. Pyza, M. Wasiak,The importance of transport infrastructure in the movement of cargo in logistics term,„Technical Transactions. Mechanics” 2011/4.

${ }^{8}$ M. Farhadi op. cit., s. $73-90$.

${ }^{9}$ W. Jarosiński Periodic technical inspections of vehicles and road traffic safety with the number of road accidents involving fatalities,Farhadi Eksploatacja i Niezawodność - Maintenance and Reliability" 16/1 (2014), s. 105-111.

${ }^{10}$ Rozporządzanie Ministra Transportu i Gospodarki Morskiej z 2 marca 1999 roku w sprawie warunków technicznych, jakim powinny odpowiadać drogi publiczne i ich usytuowanie (Dz.U. z 14 maja 1999, nr 43, poz. 430).

${ }^{11} \mathrm{~J}$. Barcik, P. Czech,Wpływ infrastruktury drogowej na bezpieczeństwo ruchu - część 1,„Zeszyty Naukowe Politechniki Śląskiej” 2010/67. 
stanowi jedynie 4,7\% sieci dróg publicznych ogółem, to przenosi ponad $60 \%$ ruchu. Konieczna jest systematyczna poprawa stanu technicznego polskiej sieci dróg krajowych w celu wyeliminowania jej podstawowych ograniczeń oraz jej rozbudowa. Do najpoważniejszych wad polskiej sieci drogowej należą zwłaszcza: brak spójnej sieci autostrad i dróg ekspresowych; brak dostosowania do przenoszenia nacisku $115 \mathrm{kN} /$ oś (zgodnie ze zobowiązaniami wynikającymi z Traktatu Akcesyjnego) oraz ruch o dużym natężeniu, w tym samochodów ciężarowych, przebiegający przez rozwijające się wzdłuż osi drogowych tereny zabudowane. Polska zobowiązała się do realizacji sieci bazowej TEN-T do 2030 r., natomiast sieci kompleksowej - do roku 2050. W obliczu dynamicznego wzrostu transportu drogowego, zarówno w kontekście przewozów towarowych, jak i pasażerskich, oraz biorąc pod uwagę wciąż niedostatecznie rozwiniętą sieć drogową, Polska nadal stoi przed wyzwaniem dokończenia budowy spójnej sieci autostrad i dróg ekspresowych, która umożliwi wzrost spójności międzyregionalnej, przyczyniając się do pełnego wykorzystania potencjału gospodarczego kraju. Transport samochodowy, którego udział w przewozach pasażerów i towarów w Polsce wynosi odpowiednio 85\% i 82\% (według stanu na 2011 r.), jest wyższy od średniej europejskiej i nadal rośnie ${ }^{12}$.Dzięki Programowi Budowy Dróg Krajowych na lata 2011-2015, który stanowił kontynuację Programu Budowy Dróg Krajowych na lata 20082012 od listopada 2007 r. do końca 2013 r. wybudowano: 835,3 km autostrad, 955 km dróg ekspresowych, 212,9 km obwodnic oraz 687,8 km ważniejszych przebudów i wzmocnień dróg krajowych. Zakładany w Programie Budowy Dróg Krajowych na lata 2011-2015próg 66\% dróg krajowych o dobrej nawierzchni ${ }^{13}$ został osiągnięty w $2013 \mathrm{r}^{14}$. Osiągnięcie dobrych wyników powinno cieszyć zwłaszcza użytkowników dróg publicznych, jednakże ta sytuacja może się zmieniać. Eksploatacja dróg jest niezwykle silna, ponieważ przez Polskę przebiegają trasy tranzytowe, przybywa coraz więcej samochodów osobowych, Polska posiada specyficzne i zróżnicowane warunki pogodowe, gdzie temperatura może wahać się od $-30^{\circ} \mathrm{C}$ do $+40^{\circ} \mathrm{C}$, co ma znaczący wpływ na zużywanie się nawierzchni. Im lepsza infrastruktura drogowa tym większa szansa na rozwój branży TSL ${ }^{15}$.Dlatego niezwykle ważne jest prowadzenie systematycznych badań dotyczących eksploatacji dróg, bezpieczeństwa drogowego oraz infrastruktury drogowej. Dzięki szybkiemu zdiagnozowaniu, gdzie sytuacja jest najgorsza, można szybko reagować i skierować strumień środków właśnie w te miejsca (województwa, powiaty), gdzie ten stan jest najgorszy.

Celem artykułu jest diagnoza infrastruktury drogowej w województwach w Polsce oraz charakterystyka eksploatacji sieci drogowej. Do badań wykorzystano dane z zasobów GDDKiA oraz ze stron GUS. Dane obejmują 2014 r. Obliczenia wykonano za pomocą dwóch programów: Statistica 10.1 oraz Excel 10.

\footnotetext{
${ }^{12}$ Program budowy dróg krajowych na lata 2014-2023, Załącznik do uchwały Rady Ministrów, Warszawa 2014.

${ }^{13}$ Wartość wynika z raportu SOSN - System Oceny Stanu Nawierzchni, wykonywanego corocznie przez GDDKiA.

${ }^{14}$ Program budowy dróg krajowych na lata 2014-2023, Załącznik do uchwały Rady Ministrów, Warszawa 2014.

${ }^{15} \mathrm{~W}$. Piekarski, S. Juściński,Rozwój sektora usług: TRANSPORT-SPEDYCJA-LOGISTYKA w Polsce po wstapieniu do Unii Europejskiej,„Eksploatacja i Niezawodność - Maintenance and Reliability” 2005/4.
} 


\section{STAN NAWIERZCHNI DRÓG W POLSCE W 2014 ROKU}

Na początku każdego roku Generalna Dyrekcja Dróg Krajowych i Autostrad (GDDKiA) publikuje raport o stanie technicznym sieci dróg krajowych. Raport ma na celu zoptymalizowanie procesu zarządzania istniejącą już siecią drogową na podstawie corocznego badania. Informacje w raporcie dotyczą sieci dróg zarządzanych przez GDDKiA (nie obejmuje on odcinków dróg przebiegających przez miasta na prawach powiatu z wyłączeniem dróg klasy A i S).Raport opracowany jest na podstawie wyników pomiarów cech technicznoeksploatacyjnych nawierzchni, które są nazywane parametrami i dotyczą przede wszystkim:

- $\quad$ spękań (pozwalających uzyskać wstępne informacje dotyczące nośności);

- równości podłużnej, głębokości kolein (równości poprzecznej);

- $\quad$ stanu powierzchni, właściwości przeciwpoślizgowych oraz

- $\quad$ ugięć nawierzchni (są to dane uzupełniające) ${ }^{16}$.

Każdy z mierzonych parametrów kwalifikowany jest według czterostopniowej skali: A stan dobry, B -zadowalający, C -niezadowalający oraz D -zły. Po kwalifikacji parametrów, następuje kwalifikacja odcinków nawierzchni do jednej z czterech klas. Służą one do wyznaczania oceny ogólnej stanu nawierzchni jezdni - wyznaczania trzech poziomów decyzyjnych stanów nawierzchni: poziomu pożądanego (stan dobry A i B), ostrzegawczego (stan niezadowalający C) oraz krytycznego (stan zły D).

Generalna Dyrekcja Dróg Krajowych i Autostrad ustala odcinki wymagające pilnej interwencji, a następnie w ramach dostępnych środków finansowych dokonuje niezbędnych prac $\mathrm{w}$ celu poprawy standardu ich użytkowania oraz podniesienia poziomu bezpieczeństwa. Zadania wymagające realizacji zostały zhierarchizowane w czterech programach i planach:

- plan działań na sieci drogowej;

- $\quad$ program redukcji liczby ofiar śmiertelnych;

- $\quad$ program budowy ciągów pieszo-rowerowych;

- program działań na sieci drogowej w zakresie drogowych obiektów inżynierskich.

Zadania w ramach poszczególnych programów i planów uporządkowano w ściśle ustalonej kolejności od najpilniejszych do wykonania. Zgodnie $\mathrm{z}$ algorytmem porządkującym szczególnie bierze się pod uwagę: wyniki badań stanu nawierzchni (wskaźnik oceny nawierzchni), wielkość i strukturę ruchu, ze szczególnym uwzględnieniem udziału samochodów ciężarowych (wskaźnik ruchu pojazdów ciężarowych, wskaźnik ruchu pojazdów osobowych), parametry drogi (wskaźnik nienormatywnej szerokości, wskaźnik rodzaju nawierzchni, wskaźnik szorstkości) oraz wskaźniki liczby zabitych i rannych (wskaźnik zabitych, wskaźnik rannych). Przyjęte kryteria pozwalają na efektywne wykorzystanie środków finansowych i umożliwiają podejmowanie działań, w pierwszej kolejności na odcinkach dróg stwarzających największe zagrożenie dla bezpieczeństwa użytkowników ${ }^{17}$.

Klasa drogi określa potrzeby związane z siecią drogową i działaniami, jakie powinny być wykonane. Potrzeby te dzielą się na natychmiastowe, które dotyczą odcinków w stanie złym, oraz potrzeby łączne dotyczące odcinków w stanie złym oraz w stanie niezadowalającym. Są także zabiegi konieczne, czyli naprawcze, które należy wykonać niezwłocznie - dotyczą one

\footnotetext{
${ }^{16}$ Raport o stanie technicznym sieci dróg krajowych na koniec 2014 roku, GDDKiA, Warszawa 2015.

${ }^{17}$ Program budowy dróg krajowych na lata 2014-2023, Załącznik do uchwały Rady Ministrów, Warszawa 2014.
} 
odcinków w stanie złym, zabiegi zalecane zaś to zabiegi naprawcze, które należy wykonać w najbliższym czasie na odcinkach znajdujących się w stanie niezadowalającym, aby nie znalazły się w stanie krytycznym. Zabiegi naprawcze podzielone są na trzy grupy:

- $\quad$ zabiegi powierzchniowe - jest to grupa zabiegów polepszających stan powierzchni i właściwości przeciwpoślizgowe;

- $\quad$ zabiegi wyrównujące - to takie, które poprawiają równość podłużną, likwidujących koleiny, polepszających stan powierzchni i właściwości przeciwpoślizgowe;

- zabiegi modernizujące - to grupa zabiegów poprawiających wszystkie oceniane parametry techniczno-eksploatacyjne nawierzchni.

Odcinki dróg znajdujących się w poszczególnych klasach dla każdego z ocenianych parametrów techniczno-eksploatacyjnych przedstawiono na rysunku 1.

Najmniej korzystne wyniki odnotowano w przypadku parametru właściwości przeciwpoślizgowe. Znaczna część dróg znajduje się w stanie krytycznym z powodu kolein, natomiast najlepsze wyniki zostały odnotowane w zakresie równości podłużnej (rys.2). Na zmianę stanu technicznego nawierzchni dróg krajowych mają wpływ przede wszystkim dwa czynniki: warunki atmosferyczne związane z częstym przechodzeniem temperatury przez punkt $0^{\circ} \mathrm{C}$ w okresie zimy oraz odnotowanymi wysokimi temperaturami w lecie (zjawiska te mają istotny wpływ na przyspieszenie procesu degradacji nawierzchni jezdni, w tym zmniejszenie jej trwałości zmęczeniowej). Drugim znaczącym czynnikiem pogarszającym nawierzchnię jest rosnący ruch pojazdów ciężarowych, przekładający się na przyspieszenie amortyzacji technicznej dróg ${ }^{18}$.

Stan nawierzchni dróg krajowych w latach 2000-2014 przedstawiono na rysunku 2. Od początku badanego okresu widać wyraźnie, że stan dróg w Polsce się poprawia. Początkowo, jako dobre zostało ocenionych $24 \%$ dróg, w 2014 roku zaś było to już $62 \%$, a więc tendencja jest wyraźna i wzrostowa.

Stan nawierzchni dróg krajowych w poszczególnych województwach nie jest jednolity. Jak wskazują analizy parametrów techniczno-eksploatacyjnych prowadzone przez GDDKiA, uwidaczniają się następujące zależności: koleiny występują przeważnie w większości województw centralnych i wschodnich. Niskie właściwości przeciwpoślizgowe notowane są w województwach południowych oraz w Polsce centralnej. Rozkłady klas równości podłużnej są bardzo podobne, ale za to bardzo zróżnicowany jest rozkład stanu spękań. Ogólną ocenę stanu dróg w województwach przedstawiono na rysunku 3.

\footnotetext{
${ }^{18}$ Raport o stanie technicznym sieci dróg krajowych...
} 
Rys.1. Procentowy udział odcinków w poszczególnych klasach stanu nawierzchni dla każdego z parametrów techniczno-eksploatacyjnych

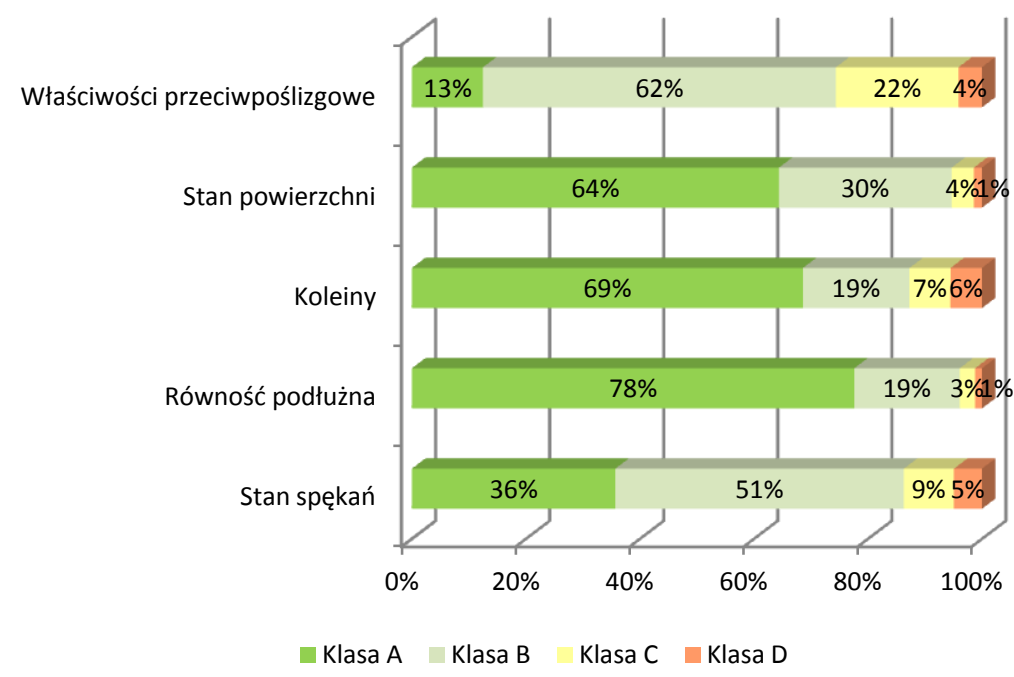

Źródło: opracowanie własne na podstawie Raportu o stanie technicznym sieci dróg krajowych na koniec 2014 roku, GDDKiA, Warszawa 2015.

Rys.2. Stan nawierzchni dróg krajowych w Polsce w latach 2000-2014

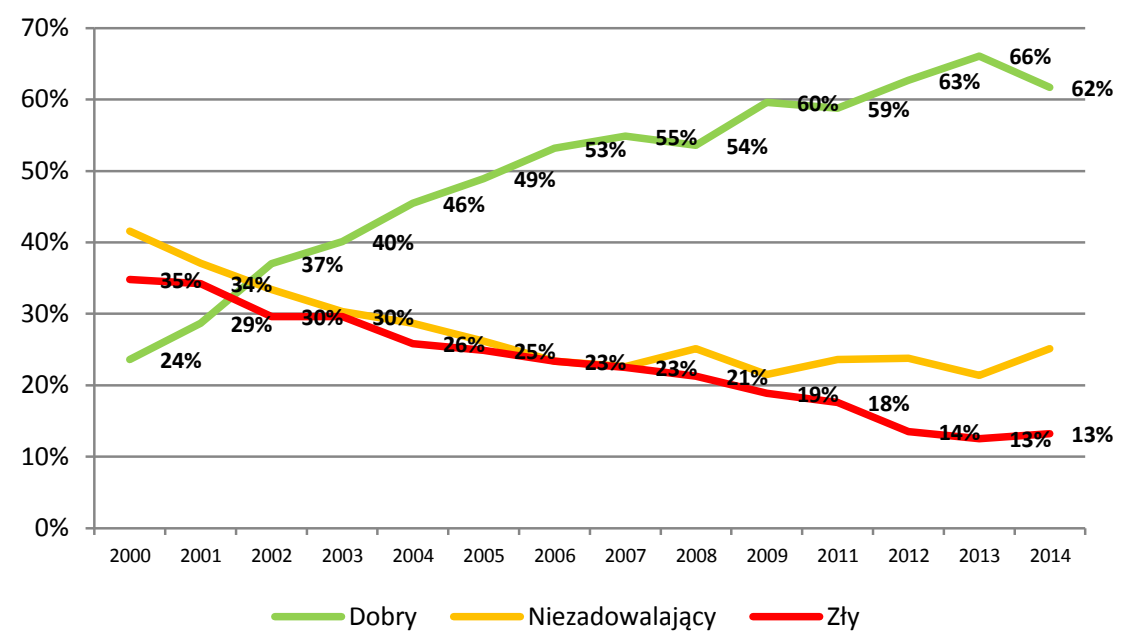

Źródło: opracowanie własne na podstawie raportów o stanie technicznym sieci dróg krajowych wydanych przez GDDKiA. 
Do określenia natychmiastowych potrzeb remontowych i łącznych potrzeb używa się dwóch wskaźników: natychmiastowych potrzeb (wskaźnik d), który stanowi stosunek długości sieci w stanie złym do długości sieci administrowanej w danym województwie, oraz łącznych potrzeb (wskaźnik cd) - stanowi on stosunek długości sieci w stanie złym i niezadowalającym do długości sieci administrowanej w danym województwie. W 2014 r. średni wskaźnik natychmiastowych potrzeb wyniósł 0,13 , a łącznych potrzeb był równy 0,37 . Największe natychmiastowe potrzeby remontowe mają województwa dolnośląskie i lubuskie. Najwyższe łączne potrzeby remontowe występują w województwach kujawsko-pomorskim, świętokrzyskim, wielkopolskim, mazowieckim i dolnośląskim ${ }^{19}$.

Rys.3. Stan nawierzchni dróg krajowych w poszczególnych województwach Polski

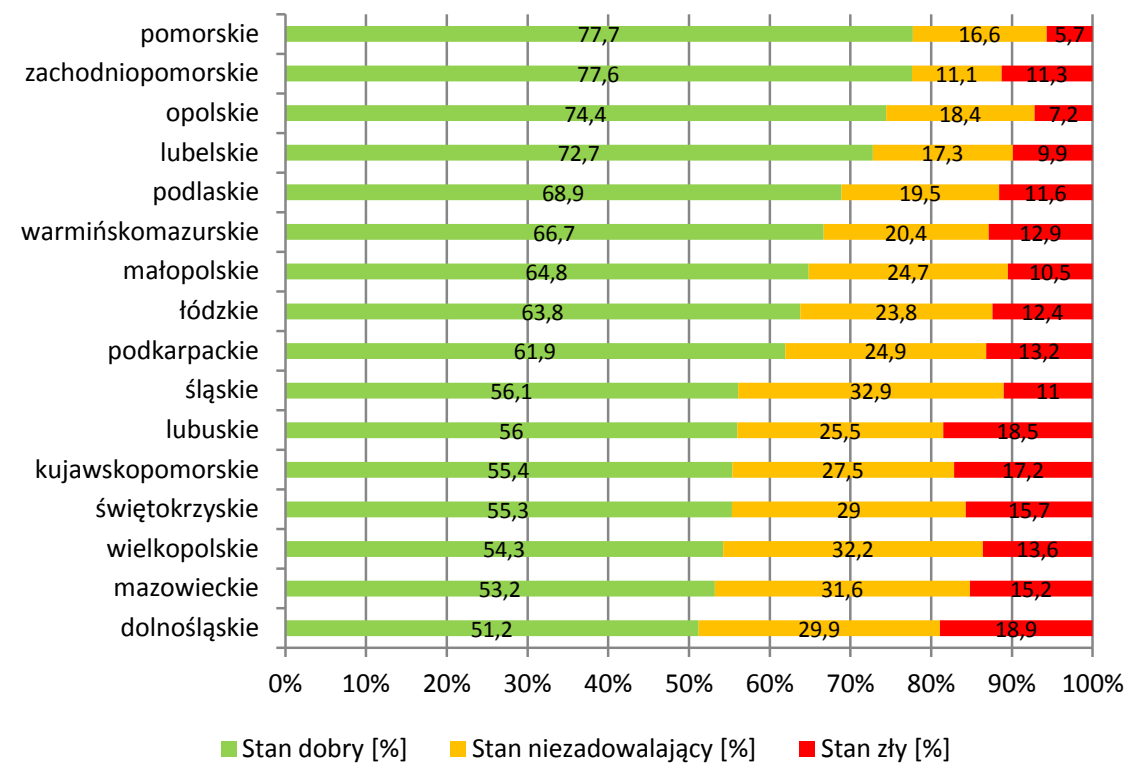

Źródło: opracowanie własne.

Stan sieci dróg krajowych jest zróżnicowany, a jednym z podwodów tego zróżnicowania jest obciążenie sieci dróg krajowych w poszczególnych województwach.

\section{METODOLOGIA}

W badaniach posłużono się metodami wielowymiarowej analizy porównawczej - analizą skupień. Termin ten został wprowadzony przez R. Tryona ${ }^{20}$,a następnie rozwinięty przez R. Cattele'a $^{21}$. Umożliwiają one jasny i precyzyjny podział badanych jednostek (w tym wypadku

\footnotetext{
${ }^{19}$ Raport o stanie technicznym sieci dróg krajowych...

${ }^{20} \mathrm{R}$. Tryon,Cluster Analysis, McGraw-Hill, New York 1939.

${ }^{21}$ R.A. Cattell,Note on correlation clusters and cluster search methods, ,Psychonometrica” 1944/9,

s. 169-184;A. Lotko, M. Lotko,Cluster analysis of knowledge workers assessment of occupational
} 
województw) charakteryzowanych przez wiele cech (ostatecznie do badań przyjęto 10 wskaźników) na skupienia (grupy, klastry) obiektów podobnych do siebie pod względem przyjętych do badań cech. Metody te stosuje się w wielu dziedzinach naukowych. Dzięki temu można sprawdzić, w jakim stopniu rozwinięta jest infrastruktura drogowa w poszczególnych województwach, jak wygląda bezpieczeństwo drogowe, a także, jaki jest stan eksploatacji dróg w powstałych klastrach. Do charakterystyki cech posłużono się podstawowymi statystykami opisowymi. Do analizy wykorzystano jednąz aglomeracyjnych metod grupowania - metodę Warda, która wykorzystuje w swoich procedurach podejście analizy wariancji ${ }^{22}$.Zmierza ona do minimalizacji sumy kwadratów odchyleń dowolnych dwóch skupień, które mogą zostać uformowane na każdym etapie badań. Jest jedną $\mathrm{z}$ najbardziej efektywnych metod grupowania. Kolejność postępowania w metodzie Warda jest podobna jak w pozostałych metodach aglomeracyjnych ${ }^{23}$. Znaczące różnice występują w użytych we wzorze parametrach. Schemat postępowania jest następujący: rozpoczyna się od wyznaczenia macierzy odległości taksonomicznych o wymiarach n x n, która zawiera odległość każdej pary obiektów. Macierz jest symetryczna względem głównej przekątnej, którą stanowią same zera. Następnie wyszukane zostają pary obiektów (a w dalszej części skupień), dla których wzajemna odległość jest najmniejsza. Przyjąć należy, że obiekty oznacza się jako „p”i „,", przy czym p<q. Kolejno następuje złączenie ,„pi ,q"w jedno nowe skupienie, które zajmuje pozycję o numerze „p". Jednocześnie usuwa się obiekt (skupienie) o numerze „q", a numery skupień o numerze od niego wyższym zmniejsza się o jeden. W ten sposób wymiar macierzy zmniejsza się o 1. Wyznacza się odległość nowego skupienia od każdego pozostałego według wzoru:

$$
D_{p r}=a_{1} \cdot d_{p r}+a_{2} \cdot d_{q r}+b \cdot d_{p q}
$$

$\mathrm{D}_{\mathrm{pr}}$ - odległość nowego skupienia od skupienia o numerze ,, $\mathrm{r}$

$\mathrm{d}_{\mathrm{pr}}$ - odległość pierwotnego skupienia ,p”od skupienia ,r"

$\mathrm{d}_{\mathrm{qr}}-$ odległość pierwotnego skupienia „,"od skupienia ,„"

$\mathrm{d}_{\mathrm{pq}}-$ wzajemna odległość pierwotnych skupien , ,p”i ,,q"

$a_{1}, a_{2}, b-$ parametry, które w metodzie Warda oblicza się na podstawie wzorów:

$$
a_{1}=\frac{n_{p}+n_{r}}{n_{p}+n_{q}+n_{r}} a_{2}=\frac{n_{q}+n_{r}}{n_{p}+n_{q}+n_{r}} b=\frac{-n_{r}}{n_{p}+n_{q}+n_{r}(2)}
$$

we wzorach „n” oznacza liczebność pojedynczych obiektów w poszczególnych grupach.

Do opisu powstałych klastrów użyto metody średnich grupowych. Polega ona na obliczeniu średniej globalnej dla poszczególnych $\operatorname{cech}\left(\bar{X}_{\mathrm{G}}\right)$ oraz średnich cech dla poszczególnych grup $\overline{\mathrm{X}}_{\mathrm{I} . . .} \overline{\mathrm{X}}_{\mathrm{N}}$. Następnie oblicza się ilorazy, które pozwalają określić, czy analizowana cecha $\mathrm{w}$ danym skupieniu przyjmuje wartości wyższe czy niższe od średniej globalnej. Jedynka oznacza taki sam poziom, jaki ma średnia globalna.

threats and attitudes of work, "Eksploatacja i Niezawodność - Maintenance and Reliability" 17/1 (2015), s. 80-89.

${ }^{22}$ T. Grabiński,Metody aksonometrii, Wydawnictwo Akademii Ekonomicznej w Krakowie, Kraków 1992.

${ }^{23}$ Statistica 10.1.PL. 


\section{ZRÓŻNICOWANIE WOJEWÓDZTW POD WZGLĘDEM JAKOŚCI DRÓG, ICH EKSPLOATACJI ORAZ BEZPIECZEŃSTWA - WYNIKI BADAŃ}

Do badań zaproponowano trzy grupy wskaźników.

Pierwsza obejmuje ocenę jakości dróg oraz potrzeby remontowe (eksploatacja):

$\mathrm{X}_{1}-$ udział procentowy dróg $\mathrm{w}$ stanie dobrym, $\mathrm{X}_{2}-$ udział procentowy dróg $\mathrm{w}$ stanie złym.

Druga grupa wskaźników charakteryzuje jakość i zagęszczenie sieci drogowej:

$\mathrm{X}_{3}$-drogi o twardej nawierzchni ulepszonej na $100 \mathrm{~km}^{2}, \mathrm{X}_{4}$-drogi zamiejskie o twardej nawierzchni ulepszonej na $100 \mathrm{~km}^{2}, X_{5}$-drogi gminne $\mathrm{i}$ powiatowe o gruntowej nawierzchni na $100 \mathrm{~km}^{2}, \mathrm{X}_{6}$-drogi ekspresowe i autostrady na $100 \mathrm{~km}^{2}$.

Trzecia grupa to wskaźniki mówiące o natężeniu ruchu na drogach oraz jego bezpieczeństwie:

$\mathrm{X}_{7}$-samochody osobowe na tys. ludności, $\mathrm{X}_{8}$ - samochody ciężarowe na tys. ludności, $\mathrm{X}_{9}$-ofiary śmiertelne na 100 tys. pojazdów, $\mathrm{X}_{10}$ - liczba wypadków na 100 tys. ludności.

Początkowo zbiór potencjalnych cech diagnostycznych był dużo większy, ale po wstępnej analizie współczynników zmienności usunięto z badań te cechy, dla których współczynniki zmienności były poniżej 10\% (wyjątek stanowi wskaźnik dotyczący samochodów osobowych przypadających na tys. ludności, który mimo poziomu wynoszącego $8 \%$ został pozostawiony do dalszych badań). Jest to ważna cecha wskazująca na nasilenie ruchu w badanych województwach, co wiąże się z eksploatacją dróg - a więc jest ona istotna dla analizy badanego zjawiska. Przeprowadzono także analizę korelacji i z badań usunięto cechy mocno skorelowane z tymi, które pozostały do badań, dlatego ostatecznie zbiór zmiennych do badań obejmuje 10 wskaźników (tab. 2).Udział procentowy dróg w stanie dobrym jest najwyższy w województwie pomorskim (78\%), a najniższy w województwie dolnośląskim (51\%). Drogi o twardej nawierzchni ulepszonej, podobnie jak drogi ekspresowe i autostrady przypadające na $100 \mathrm{~km}^{2}$ najwyższą wartość przybierają w województwie śląskim. Najmniejsze wartości przypadają na województwa północno-wschodnie, podlaskie i warmińsko-mazurskie. W podlaskim natomiast jest najwięcej dróg gminnych powiatowych o gruntowej nawierzchni przypadających na $100 \mathrm{~km}^{2}$. Najmniejszy udział tych dróg jest w województwie opolskim.

Tabela 1. Statystyki opisowe zmiennych przyjętych do badań (wyniki zaokrąglone do całości)

\begin{tabular}{|c|c|c|c|c|}
\hline & $(\bar{x} \pm \sigma)$ & Min. & Maks. & $\mathrm{V}_{\mathrm{z}}$. \\
\hline $\mathrm{X}_{1}$ udział procentowy dróg w stanie dobrym & $(63 \pm 9)$ & 51 & 78 & 14 \\
\hline $\mathrm{X}_{2}$ udział procentowy dróg w stanie złym & $(13 \pm 4)$ & 6 & 19 & 29 \\
\hline $\mathrm{X}_{3}$ drogi o twardej nawierzchni ulepszonej na $100 \mathrm{~km}^{2}$ & $(87 \pm 33)$ & 50 & 175 & 38 \\
\hline $\mathrm{X}_{4}$ drogi zamiejskie o twardej nawierzchni ulepszonej na $100 \mathrm{~km}^{2}$ & $(67 \pm 20)$ & 42 & 116 & 29 \\
\hline $\mathrm{X}_{5}$ drogi gminne i powiatowe o gruntowej nawierzchni na $100 \mathrm{~km}^{2}$ & $(40 \pm 14)$ & 22 & 68 & 35 \\
\hline $\mathrm{X}_{6}$ drogi ekspresowe i autostrady na $100 \mathrm{~km}^{2}$ & $(1 \pm 0,55)$ & 0,16 & 2 & 59 \\
\hline $\mathrm{X}_{7}$ samochody osobowe na tys. ludności & $(496 \pm 39)$ & 434 & 564 & 8 \\
\hline $\mathrm{X}_{8}$ samochody ciężarowe na tys. ludności & $(82 \pm 12)$ & 70 & 110 & 14 \\
\hline $\mathrm{X}_{9}$ ofiary śmiertelne na 100 tys. pojazdów & $(14 \pm 3)$ & 10 & 18 & 19 \\
\hline $\mathrm{X}_{10}$ liczba wypadków na 100 tys. ludności & 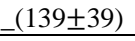 & 85 & 220 & 28 \\
\hline
\end{tabular}

Źródło: opracowanie własne na podstawie danych GUS i GDDiK.

Park samochodowy najliczniejszy jest w województwie wielkopolskim (samochody osobowe) oraz w mazowieckim (samochody ciężarowe), a najmniejszy w województwie 
podlaskim (samochody osobowe) oraz w województwie podkarpackim i warmińskomazurskim (samochody ciężarowe).

Ostatni obszar to bezpieczeństwo na drodze. Najmniej wypadkowym województwem jest kujawsko-pomorskie, a do największej liczby wypadków dochodzi w województwie łódzkim. Nie idzie to w parze $\mathrm{z}$ ofiarami śmiertelnymi, gdyż najmniej ofiar śmiertelnych przypada na 100 tys. pojazdów w województwie śląskim, a najwięcej w województwie warmińskomazurskim.

W celu sprawdzenia zależności między przyjętymi wskaźnikami charakteryzującymi trzy obszary związane z transportem i jego bezpieczeństwem sporządzono macierz korelacji, dzięki której można przeanalizować związki między badanymi wskaźnikami. W wypadku zbyt dużych zależności $(>0,9)$ jedną $\mathrm{z}$ badanych cech należałoby usunąc $\mathrm{z}$ badań, ponieważ przenoszą one ten sam zasób informacji.

Po przeanalizowaniu cech można stwierdzić, że nie występują wysokie związki między przyjętymi wskaźnikami. Najwyższy wskaźnik $82 \%$ wystąpił w wypadku udziału procentowego dróg w stanie dobrym i w stanie złym. Współczynnik jest ujemny i odwrotnie proporcjonalny -wraz ze wzrostem udziału procentowego dróg w stanie dobrym spada udział procentowy dróg w stanie złym. Nie jest to związek pełny, bo występuje jeszcze jedna kategoria dróg o stanie niezadowalającym. W związku z tym, że współczynnik ten jest mniejszy niż $90 \%$, pozostawiono obie cechy w dalszych badaniach, zwłaszcza, że pozwolą one na dokładną charakterystykę eksploatacji dróg w województwach. Zależności można przedstawić na wykresie workowym.

Z wykresu workowego (rys.4) wyraźnie widać dwa województwa, które mają wysoki udział dróg w stanie dobrym (oznaczone na wykresie jako odstające województwo pomorskie i zachodniopomorskie) oraz dolnośląskie, które ma największy odsetek dróg w stanie złym.

Po ostatecznym ustaleniu wskaźników, które znalazły się w badaniach, przeprowadzono procedurę grupowania. Grupowanie wykonano z wykorzystaniem metody Warda. Polega ona na minimalizowaniu wariancji wewnątrz powstałych skupień (grup) (4), a więc obiekty zgrupowane w jednym skupieniu są do siebie bardzo podobne pod względem wybranych cech.

Rys.4. Współczynnik korelacji pomiędzy stanem dobrym a stanem złym dróg podanym w udziale procentowym

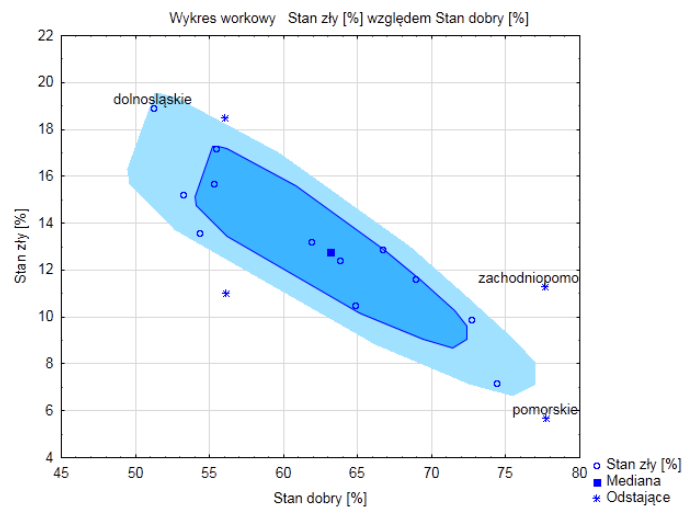

Źródło: opracowanie własne. 
Na podstawie przeprowadzonych badań powstałytrzy grupy województw różniących się między sobą poziomem eksploatacji dróg, stanem infrastruktury drogowej oraz bezpieczeństwem na drogach (rys. 5). Do I grupy można zaliczyć województwa: łódzkie, świętokrzyskie, małopolskie i śląskie. W skład grupy Ilwchodzi pięć województw: mazowieckie, wielkopolskie, lubuskie, kujawsko-pomorskie oraz dolnośląskie. W skupieniu III znalazły się pozostałe województwa: lubelskie, podlaskie, podkarpackie, zachodniopomorskie, warmińsko-mazurskie, opolskie oraz pomorskie. Które z cech zadecydowały o powstaniu poszczególnych skupień wskazuje wykres radarowy, na którym uwidoczniono poziomy średnich grupowych. Numery skupień nie sugerują poziomu infrastruktury, jakości i bezpieczeństwa na drogach.

W skupieniu I znalazły się województwa z Polski południowej i centralnej. Najwyższe wartości przyjmują tu wskaźniki dotyczące liczby dróg o twardej nawierzchni ulepszonej na $100 \mathrm{~km}^{2}$, drogi zamiejskie o twardej nawierzchni ulepszonej przypadające na $100 \mathrm{~km}^{2}$ oraz drogi ekspresowe i autostrady przypadające na $100 \mathrm{~km}^{2}$. Można więc stwierdzić, że infrastruktura drogowa jest wysoko rozwinięta. Stan dróg jest przeciętny. Najniższą wartość przyjmuje wskaźnik dotyczący dróg gminnych i powiatowych o gruntowej nawierzchni przypadających na $100 \mathrm{~km}^{2}$. Niestety grupa ta ma wysokie wartości wskaźnika odpowiadającego za liczbę wypadków przypadających na 100 tys. pojazdów, na szczęście wskaźnik informujący o ofiarach śmiertelnych na 100 tys. pojazdów nie jest wysoki. Średnie wartości przyjmują wskaźniki odpowiedzialne za natężenie liczby zarejestrowanych samochodów ciężarowych i osobowych w ogóle.

Rys.5.Grupowanie województw ze względu na stan infrastruktury drogowej, eksploatacji dróg oraz bezpieczeństwa na drogach

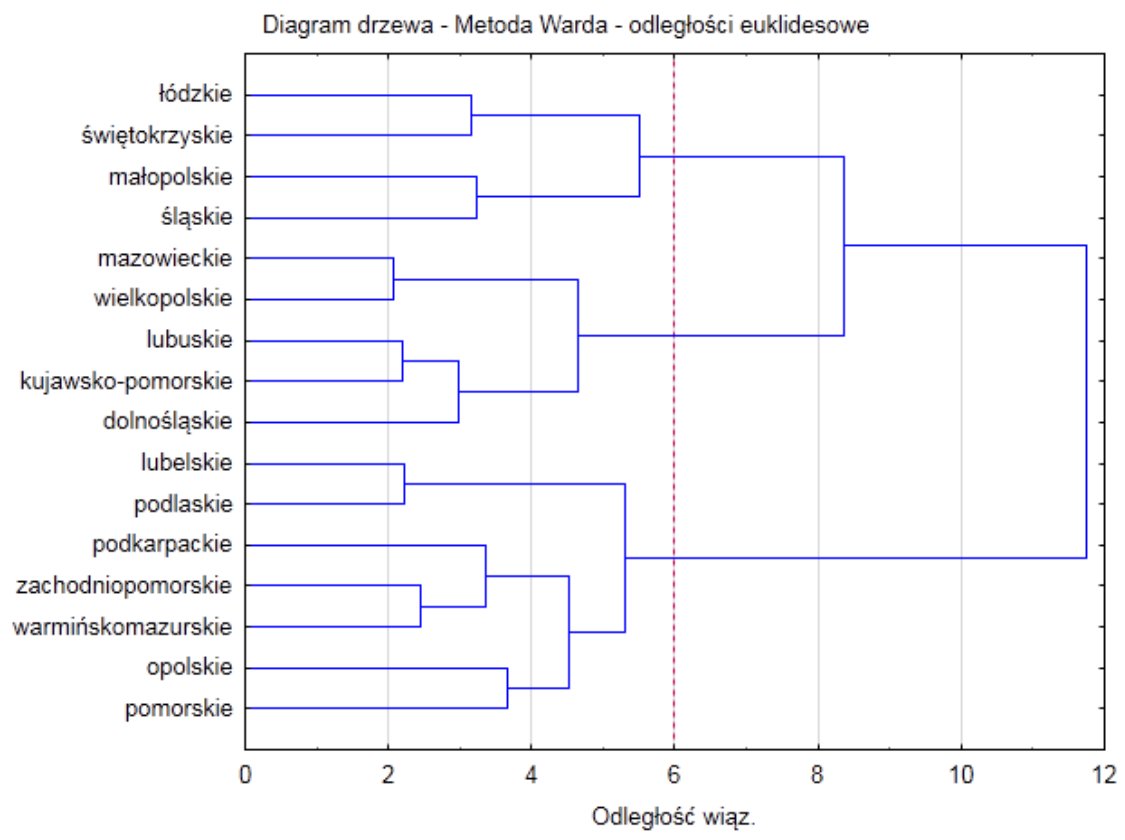

Źródło: opracowanie własne. 
Grupa II to pas województw centralnych, łączących zachód ze wschodem Europy. Charakteryzują się one w większości złym stanem dróg, na średnim poziomie kształtują się wskaźniki dotyczące infrastruktury drogowej. Ale można stwierdzić, że są to najbardziej bezpieczne województwa, ponieważ wskaźniki dotyczące bezpieczeństwa na drogach także przyjmują najmniejsze wartości. Największe spośród pozostałych grup jest obłożenie parkiem samochodowym przypadającym na tys. ludności.

Grupa III to województwa peryferyjne w większości północne i wschodnie. W tej grupie województw występuje największy odsetek dróg w stanie dobrym, niewymagających żadnych zabiegów. Niestety gęstość tych dróg jest na najniższym poziomie w porównaniu z dwoma pierwszymi skupieniami. Najmniejszy udział jest dróg ekspresowych i autostrad w przeliczeniu na $100 \mathrm{~km}^{2}$. Bezpieczeństwo na drodze jednak daje wiele do myślenia - chociaż wskaźnik liczby wypadków na 100 tys. pojazdów jest na średnim poziomie, to największą wartość przyjmuje wskaźnik dotyczący ofiar śmiertelnych przypadających na 100 tys. pojazdów. Na najniższym poziomie są wskaźniki dotyczące samochodów ciężarowych i osobowych zarejestrowanych na tys. mieszkańców.

Rys.6. Poziomy wskaźnika średnich grupowych cech diagnostycznych w poszczególnych skupieniach

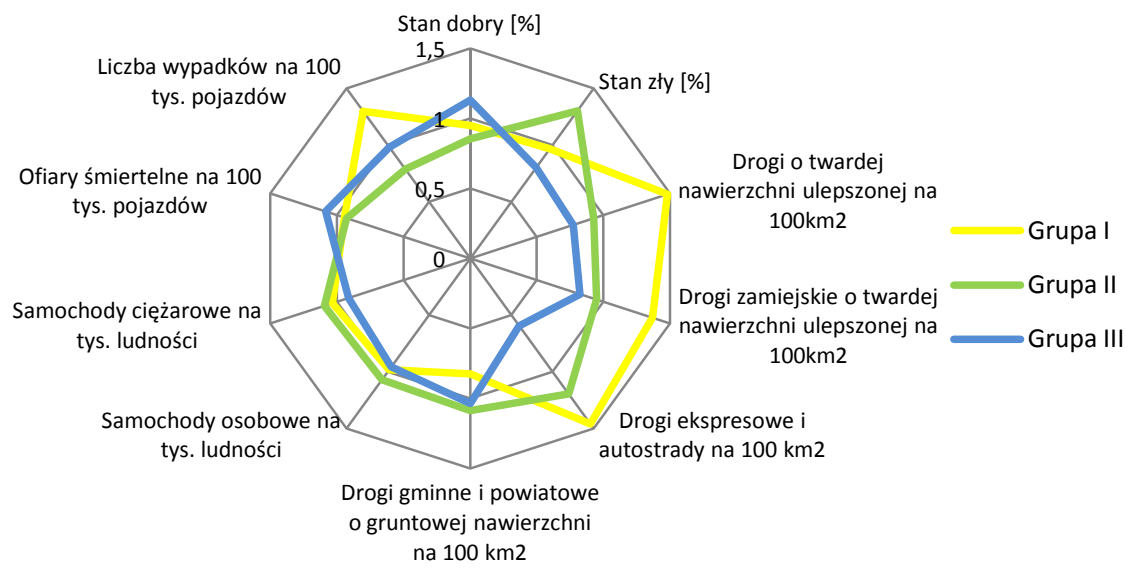

Źródło: opracowanie własne.

\section{WNIOSKI}

Analizując poszczególne grupy województw pod względem infrastruktury drogowej, stanui eksploatacji dróg oraz bezpieczeństwa na drodze, nie da się jednoznacznie określić skupień, które charakteryzowałyby się najlepszym bądź najgorszym stanem badanych dziedzin. Podział terytorialny przedstawiono na rysunku 7. Można natomiast stwierdzić, że:

- $\quad$ stan dróg w Polsce i w poszczególnych województwach poprawia się od 2000 roku; 
- $\quad$ najlepszym stanem eksploatacji dróg charakteryzują się województwa z grupy III, a najgorszym - z grupy II;

- najbardziej bezpieczne są drogi w województwach $\mathrm{z}$ grupy II, natomiast najwięcej wypadków pojawia się $\mathrm{w}$ województwach $\mathrm{Z}$ grupy I, a ofiar śmiertelnych w grupie III;

- zdecydowanie najlepszą infrastrukturę drogową mają województwa z grupy I, a najgorszą - z grupy III;

- $\quad$ park samochodowy jest najmniejszy w grupie III, a największy w grupie II.

W celu utrzymania w kolejnych latach trendu poprawy stanu technicznego nawierzchni niezbędne jest zabezpieczenie środków finansowych na potrzeby związane z pracami na nawierzchniach, w przeciwnym wypadku stan nawierzchni może się pogorszyć.

Dzięki przeprowadzonym badaniom można zdiagnozować mocne i słabe strony województw dotyczące infrastruktury transportowej oraz jej eksploatacji. Na rysunku 7 województwa łączą się w grupy, których uczestnicy są do siebie podobni pod względem przyjętych cech. Województwa te często sąsiadują ze sobą. Układając więc strategię dotyczącą rozwoju infrastruktury drogowej, można wspomagać podejmowanie decyzji metodami wielowymiarowej analizy porównawczej.

Rys.7.Graficzny rozkład stanu infrastruktury drogowej, eksploatacji dróg oraz bezpieczeństwa na drogach

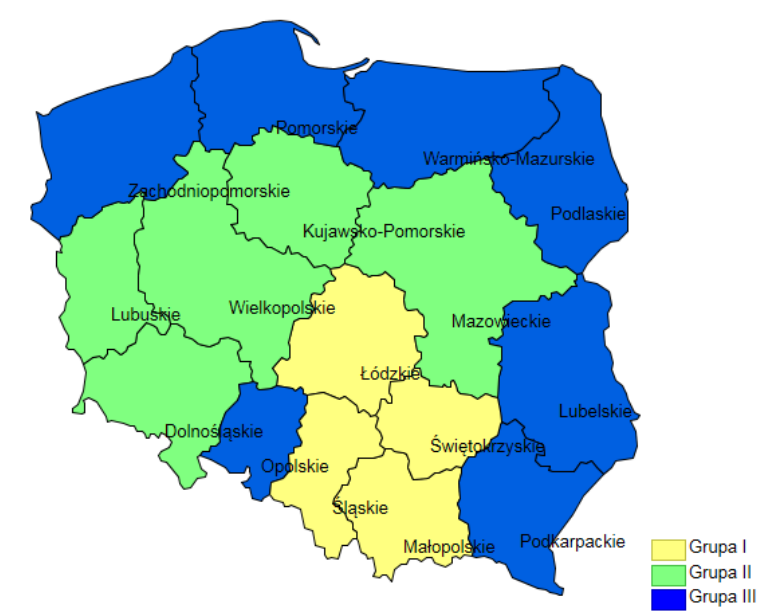

Źródło: opracowanie własne.

\section{LITERATURA}

[1] Barcik J., Czech P.,Wpływ infrastruktury drogowej na bezpieczeństwo ruchu - część 1,„Zeszyty Naukowe Politechniki Śląskiej Gliwice” 2010/67.

[2] Cattell R.A.,Note on correlation clusters and cluster search methods,,Psychonometrica” 1944/9, s.169-184. 
[3] Farhadi M.,Transport infrastructure and long - run economic growth in OECD countries,,,Transportation Research Part A. Elsevier”2015/74, s.73-90.

[4] Grabiński T.,Metody aksonometrii, Wydawnictwo Akademii Ekonomicznej w Krakowie, Kraków1992.

[5] Jacyna M., Pyza D., Wasiak M.,The importance of transport infrastructure in the movement of cargo in logistics term,,,Technical Transactions. Mechanics"2011/4.

[6] Jarosiński W.,Periodic technical inspections of vehicles and road traffic safety with the number of road accidents involving fatalities, "Eksploatacja i Niezawodność - Maintenance and Reliability" 16/1 (2014), s. 105-111.

[7] Lotko A., Lotko M.,Cluster analysis of knowledge workers assessment of occupational threats and attitudes of work,„Eksploatacja i NiezawodnośćMaintenanceand Reliability" 17/1 (2015), s. 80-89.

[8] Mirowski W.,Studia nad infrastruktura wsi polskiej. Wyposażenie obszarów w infrastrukture społeczna,t. III,PAN Instytut Rozwoju Wsi i Rolnictwa, Warszawa 1996.

[9] Nowacki G.,Wybrane problemy dotyczace infrastruktury transportowej oraz potencjalnych zagrożen terrorystycznych,Instytut Transportu Samochodowego, Warszawa 2012.

[10] Piekarski W., Juściński S., Rozwój sektora ustug: TRANSPORT-SPEDYCJA-LOGISTYKA w Polsce po wstapieniu do Unii Europejskiej,„Eksploatacja i Niezawodność - Maintenance and Reliability” 2005/4.

[11] Program budowy dróg krajowych na lata 2014-2023, Załącznik do uchwały Rady Ministrów, Warszawa 2014.

[12] Raport o stanie technicznym sieci dróg krajowych na koniec 2014 roku, GDDKiA, Warszawa 2015.

[13] Sidor J.,Realization of the transport policy at the international, national and regional level,„Eksploatacja i Niezawodność- Maintenance and Reliability” 2006/4, s.61-66.

[14] Statistica 10.1.PL.

[15] Sturm J.E., Jacobs J., Groote P.,Output effects of infrastructure investment in the Netherlands, 1853-1913,,Journal of Macroeconomics”21/2(1999).

[16] Tryon R.,Cluster Analysis,McGraw-Hill,New York 1939.

\section{VOIVODSHIPS DELIMITATION DUE TO TRANSPORT INFRASTRUCTURE AND QUALITY OF SURFACE}

Socio-economic development of states is related to the development of transport infrastructure that enables rapid movement of people and goods. Exploitation of the road network at the present time, where the traffic is heavy, is growing. Therefore, an extremely important process is a quickly diagnosis of the condition of the surface and directing resources in the most needed regions in order to prevent even greater devastation and to take care of traffic safety. When selecting the features there was used existing knowledge and research experience. The main criterion for the selection of indicators was an access to the databases and statistical analysis. The purpose of this article is not only the diagnosis of conditions in the voivodeships in Poland, but also to link it with the road infrastructure, transport and road safety. For the studies the methods of 
multidimensional comparative analysis (MCA) have been applied. The data include 2014 year and come from the base of the Central Statistical Office and the resources of the General Directorate for National Roads and Motorways. The study has been conducted using Statistica PL 10.1 and EXCEL, 2007 for calculations. As a result of analyzes three groups were selected. The levels of analyzed indicators in these clusters are varied. However, it can be stated that since 2000 the state of Polish roads are constantly improving.

Keywords: Transport infrastructure, road infrastructure, taxonomy.

DOI:10.7862/rz.2016.hss.1

Przesłano do redakcji: styczeń 2016

Przyjęto do druku: czerwiec 2016 